\title{
Analysing Istanbul Strait Maritime Pilot Capacity by Simulation Technique
}

\author{
Emre Ucan and Selcuk Nas \\ (Maritime Facility, Dokuz Eylul University, Izmir, Turkey) \\ (E-mail: emre.ucan@deu.edu.tr)
}

\begin{abstract}
Nautical services should be allocated efficiently as they have great resource costs. In this paper, the Marine Pilotage Service in the Istanbul Strait has been analysed by using Rockwell Arena Simulation Software. The purpose of the study is to find the required number of marine pilots for vessel traffic flow in the Istanbul Strait. It is evaluated thoroughly by a stochastic, dynamic, discrete simulation for safe service standards in pilotage. The result of the paper shows that discrete simulation technique is an efficient and reliable way of solving complex techno-nautical service allocation problems as proven by experts. As the discrete simulation result data shows, most other techno-nautical services can also be modelled and optimised by using similar techniques. Areas like optimisation of the number of pilots, tugs, resource allocation problems, berthing area selections and many more complex and inherently stochastic problems can be reliably solved by simulation experiments.
\end{abstract}

\section{KEYWORDS}
1. Pilotage Services.
2. Simulation.
3. Istanbul Strait.

Submitted: 18 November 2014. Accepted: 5 November 2015. First published online: 23 December 2015.

1. INTRODUCTION. The Istanbul Strait is one of the busiest waterways in the world and one without any alternative. It is the only connection between the Black Sea and the Marmara Sea and via the Aegean to the World (Basaraner et al., 2011). The Strait also divides Turkey's biggest city which can only be described as a city where a sea lays (Magdalino, 2000). The Istanbul Strait has high importance not just because of its undeniable effect on military politics in the Black Sea but also because it is expanding the hinterland of all Black Sea countries through the Danube, Volga and Don rivers and boosting trade (Inan, 2004).

The safety of the Istanbul Strait is very important to all the nations sharing the benefits of the Strait and Turkey is the sole authority able to impose rules or regulations to regulate traffic safety in the Strait (Akten, 2003). The authority of Turkey over the Istanbul Strait differs from the 1982 United Nations Convention on Law of the Sea (UNCLOS, 1982) regulations and comes from the 1936 Montreux Convention. This 
means that Turkey's Directorate General of Coastal Safety is the authority in charge of safety of the Strait.

It is also a known fact that vessels involved in accidents during their Strait transit are mostly ones not using a pilotage service (92.8\%) (Ece, 2005). It can be assumed that good pilotage contributes markedly to safety afloat in the area.

To be efficient, a pilot must be well rested regardless of their competence. It is a fact that fatigue increases the accident risk and also damages the mental and physical health of the sea pilots (Squire, 2007). But a pilotage service is also a trade and there is considerable commercial pressure on the pilots. Even though pilots normally deny this claim, they may work overtime and it is also known that authorities neglect inspections regarding the resting hours of the pilots (Darbra et al., 2007). Thus it is important that the correct number of pilots are employed for any pilot station.

For the Istanbul Strait this is the responsibility of Turkey's Directorate General of Coastal Safety. They make the decision empirically with the assistance of its head pilots and managers. According to interviews with decision makers, when head pilots detect constant fatigue among their fellow companions, a few more pilots are recruited based on the authority's decision. After the recruitment decision, preparing a pilot for Istanbul is a lengthy process; it can take at least four years for a cadet pilot to progress to the level of a senior Istanbul Strait Pilot (Official Gazette, 2006).

Thus a more efficient approach may be to use simulation software's proven algorithms to solve the problem (Kelton et al., 2002). Simulation software is mostly used to improve a system's functionality by increasing or decreasing allocation of resources needed. It is especially important when the real system is sensitive to outside manipulation because such trials may damage the functionality of the process and/or results maybe risky or costly. Also generally it is nearly impossible to slow down or halt a real system (Chung, 2003).

There are already simulation modelling studies in the maritime industry. Mostly such studies are focused on container terminal operations and on their optimisations (Zeng and Yang, 2009; Zhang et al., 2007; Esmer and Tuna, 2010; Esmer et al., 2013). Also in maritime transportation there are studies about risk assessment for human factors (Harrald et al., 1998), risk assessment for environmental pollution in port areas (Bruzzone et al., 2000), risk assessment for inland water collisions ( $\mathrm{Li}$ and Fan, 2012), risk assessment for sea routes (Gucma, 2008), risk assessment for planned coastal facility safety (Nas, 2010; Nas and Zorba, 2012). Additionally Istanbul Strait vessel traffic has already been modelled in various studies (Ozbas et al., 2009; Yazici and Otay, 2009; Eldemir et al., 2013). But there are few studies for techno-nautical optimisation problems. In two studies simulation programs have been used to optimise tug numbers and tug docking places (Nas, 2011; Wenhui, 2011).

Thus a stochastic, dynamic, discrete simulation is chosen to analyse the required number of maritime pilots in the Istanbul Strait. An expanded version of this simulation study is the masters thesis of one of the authors (Ucan, 2013).

2. METHODOLOGY. A stochastic, dynamic, discrete simulation is designed to analyse the required pilot numbers in the Istanbul Strait Pilotage service. Qualitative and quantitative data gathering methods have been used to acquire the required data to design the mathematical model of the Istanbul Strait. A series of simulation 
experiments have been conducted to optimise the required pilot numbers. Results are analysed and presented to Turkey's Directorate General of Coastal Safety Authority (KEGM). Results are found satisfactory as scientific and logical by both parties.

2.1. Purpose of the Research. Safe passage in the Istanbul Strait is of utmost importance and pilotage is an effective way of improving safety of transit vessels. The pilotage service is the responsibility of KEGM. No computerized method has been used to optimise required pilot numbers employed in the Istanbul Strait and mainly empirical methods have been used to evaluate such judgments.

This research aims to help decision makers and stakeholders of KEGM to present a scientific method that may be used to evaluate the judgment by using simulation methods which have been used in many other optimisation problems in other industries.

2.2. Data Gathering Methods. Qualitative and quantitative research methods are used to design the best model to be used in simulation software after a through literature examination.

As a quantitative research method, a database of ships passing through the Istanbul Strait between 2010 and 2011 was acquired by kind permission from KEGM. The analysis of this database is completed by a program "Arena Input Analyser". The acquired data has been used in the design of the model.

As a qualitative research method, by the advice and permission of KEGM, the gathering of expert opinions of Head and Senior Pilots of the Istanbul Strait has been conducted. Gathered interview data has been analysed and used to shape the mathematical model. Also a huge literature research has been conducted about the rules governing the Istanbul Strait. The rules have been included in the model where necessary.

2.3. Limitations of the Research. Psychological, financial, environmental and managerial factors have been excluded from this research. All other factors that may affect the results have been omitted and only "number of pilots" is accepted as the main factor in the model according to the Pareto method. The designed mathematical model is solely developed to simulate the pilotage service in the Istanbul Strait. Vessel traffic is modelled only as required to simulate the pilotage service.

3. MODELLING OF THE PILOTAGE SERVICE. The most important part of simulation experiments is designing a reliable and valid mathematical model for the process and using the correct software tools to acquire and analyse the data. Rockwell Automation's Arena simulation software has been used in this study.

3.1. Designing the Algorithm. To prepare an algorithm, there are three important parts. First the "real problem determination". In this study this is achieved by using the Fish Bone and Pareto Method as shown in Figure 1. It is discovered that for optimisation of the required number of pilots in the Istanbul Strait, the most important factor is the number of pilots employed in a shift. As the second part; the required performance criteria output must be selected correctly. This is explained in detail in Section 3.4 but here it should be noted that "rest hours" is selected as the performance criteria. The third part is "know the system"; before the design of the algorithm a series of data gathering methods have been used to know the system and constant expert opinions were evaluated during the design phase and even after the results have been acquired; again the authors referred to expert opinions of the Head Pilots for validity. 


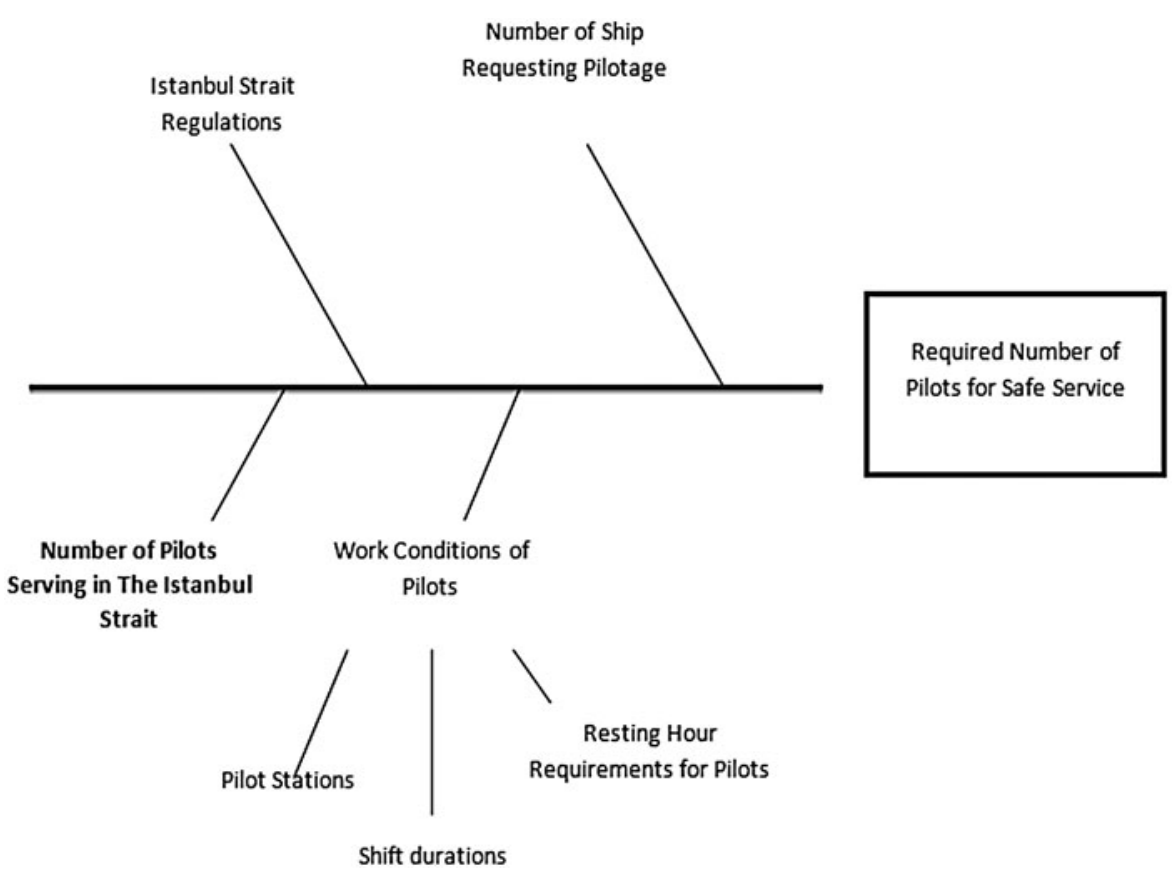

Figure 1. Fish Bone Method to Evaluate Pilot Quantity.

Table 1. Relevant Statistics About Istanbul Strait.

\begin{tabular}{lrrr}
\hline & \multicolumn{1}{l}{$\mathbf{2 0 1 0}$} & \multicolumn{1}{c}{$\mathbf{2 0 1 1}$} & $\mathbf{2 0 1 0} \& \mathbf{2 0 1 1}$ Average \\
\hline Number of Ships Arriving to Istanbul Strait & $50882 \cdot 00$ & $49808 \cdot 00$ & $50345 \cdot 00$ \\
Arriving Ships. South Bound & $25537 \cdot 00$ & $24856 \cdot 00$ & $25196 \cdot 50$ \\
Arriving Ships. North Bound & $25345 \cdot 00$ & $24952 \cdot 00$ & $25148 \cdot 50$ \\
Average Transit Duration. South Bound (Hours) & 1.54 & $1 \cdot 51$ & 1.53 \\
Average Transit Duration. North Bound (Hours) & 1.90 & 1.89 & 1.89 \\
\hline
\end{tabular}

Source: KEGM 2010-2011 Data

3.2. Selecting the Inputs. Inputs are gathered by qualitative and quantitative methods as previously noted.

3.2.1. Quantitative Inputs. The most important part of simulation experiments is designing a reliable and valid mathematical model for the process and using the correct software tools to acquire and analyse the data. As simulation software, Rockwell Automation's Arena V14 has been used and as data analysing tool, Rockwell Automation's Input Analyser has been used. For example the following Figures and Tables are extracted from KEGM's Turkish Strait statistics and presented here. In Table 1 general relevant statistics about the Istanbul Strait have been given.

Figure 2 shows an exponential spread of ships arriving to the Istanbul Strait from South to North after analysis of the KEGM data. For the algorithm, each ship type detailed by KEGM was analysed separately. Then that data was analysed to increase reliability and validity of the simulation. 

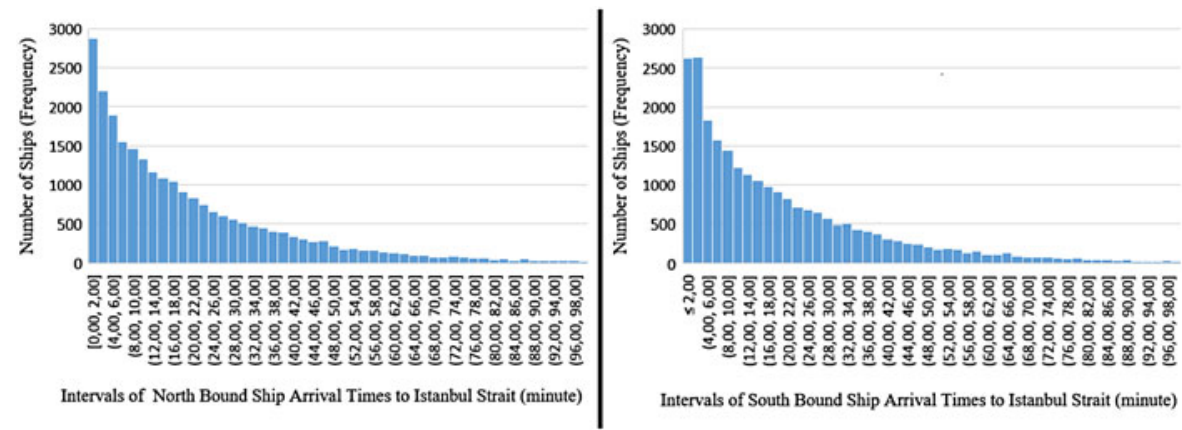

Figure 2. Exponential Spread and Empirical Ship Arrival Times to Istanbul Strait Regardless of Ship Type. (South / North Bound).

Table 2. Ship Type Ratios for Vessels Transiting The Strait According To KEGM Classification.

\begin{tabular}{|c|c|c|c|c|}
\hline & \multicolumn{2}{|c|}{ North Bound } & \multicolumn{2}{|c|}{ South Bound } \\
\hline & Number & $\%$ & Number & $\%$ \\
\hline MPR & 585 & $1 \cdot 16$ & 591 & $1 \cdot 18$ \\
\hline NAV & 96 & $0 \cdot 19$ & 104 & $0 \cdot 21$ \\
\hline G12 & 32886 & $65 \cdot 38$ & 32728 & $65 \cdot 07$ \\
\hline G3 & 5874 & 11.68 & 5966 & $11 \cdot 86$ \\
\hline G4 & 554 & $1 \cdot 10$ & 588 & $1 \cdot 17$ \\
\hline G5 & 6 & $0 \cdot 01$ & 6 & $0 \cdot 01$ \\
\hline T12 & 5163 & $10 \cdot 27$ & 5345 & $10 \cdot 63$ \\
\hline T3 & 4463 & $8 \cdot 87$ & 4417 & 8.78 \\
\hline T4-5 & 670 & 1.33 & 648 & 1.29 \\
\hline Total & 50297 & $100 \cdot 00$ & 50393 & $100 \cdot 00$ \\
\hline
\end{tabular}

Source: KEGM 2010-2011 Data

In Table 2, KEGM 2010-2011 Data has been analysed and ship types transiting the Strait are shown. Ship types are classified according to the KEGM code as follows: MPR - Passenger, Yachts, Livestock carrier; NAV - Military; ships other than Tankers without International Maritime Dangerous Goods (IMDG) Cargo: G12 ships shorter than 150 m; G3 - ships between 150-200 m; G4 - ships between 200$250 \mathrm{~m}$; G5 - ships longer than $250 \mathrm{~m}$; tankers and other ships carrying IMDG Cargo: T12 - ships shorter than 150 m; T3 - ships between 150-200 m; T4, 5 - ships longer than $200 \mathrm{~m}$; towed ships and ships larger than $300 \mathrm{~m}$.

Ship transit times of the vessels are analysed from the KEGM 2010-2011 Data. Arena Input Analyser V14 software has been used to analyse this data for distribution. In Figure $3(1+$ Erlang $(0 \cdot 222,4))$ and Figure $4(1+$ Erlang $(0 \cdot 105,5))$ (as calculated by Arena software) have been found as the most fitting exponential distribution by the programme with the least amount of chi-square error. Fitness of data and distribution can be observed in Figures 3 and 4.

Only the general traffic direction is considered to find the transit duration. The average transit time North Bound was found to be 1.88 hours, South Bound the average time was found to be 1.53 hours. But in the algorithm every ship type has been separately analysed in its class including the transit direction. 


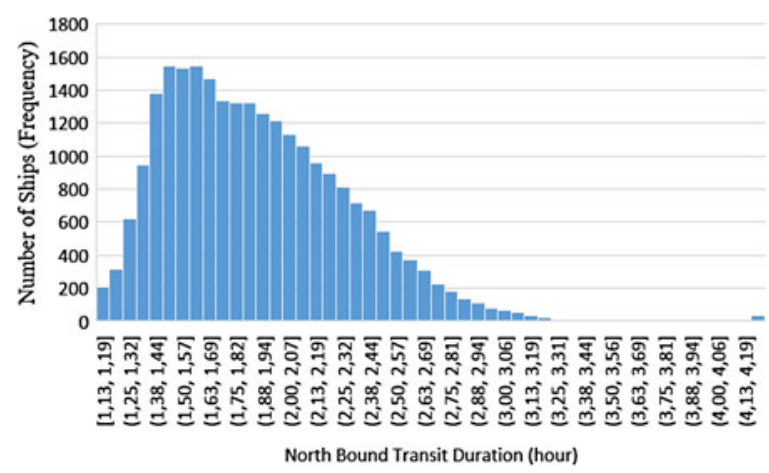

Figure 3. Erlang Distribution and Empirical Ship Transit Duration (All Ships). (North Bound)

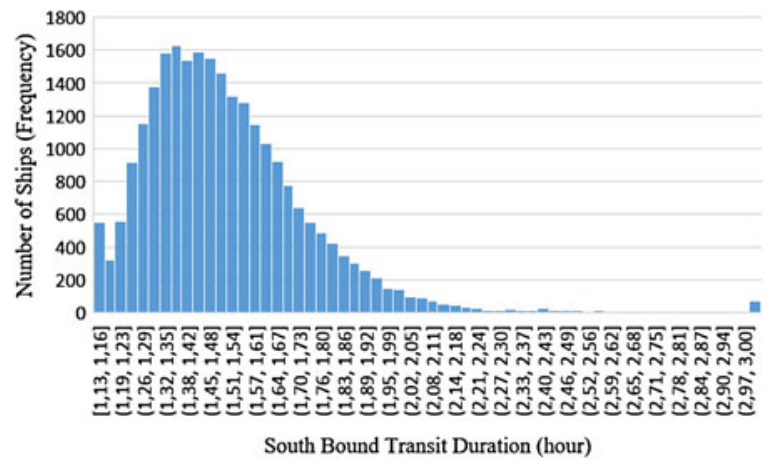

Figure 4. Erlang Distribution and Empirical Ship Transit Duration. (All Ships). (South Bound)

In Table 3, KEGM statistical data has been analysed to calculate the ratio of pilotage service requests with ship types. Here it can easily be observed that large and risky vessels have higher demand for pilotage services.

3.2.2. Qualitative Inputs. Consulting experts' opinions have been used to gather qualitative inputs. Experts have been chosen from Istanbul Strait Pilots and Vessel Traffic Services' Responsible Officers. All interviews have been conducted with the permission and guidance of KEGM. A structured interview form has been used in the research. Three Head Pilots, eight Pilots and two VTS Officers have been interviewed. The form was designed to gather data required to build a reliable and valid model of the Pilotage Service. It was specially designed to find time requirements, transfer conditions of pilots and their general work conditions and duties. The analysis of data has been conducted by the authors and compared against the statistical data gathered from KEGM.

In addition, Istanbul Strait Transit passage regulations have been examined to find a ranking algorithm for vessels arriving at the Istanbul Strait. Even though it is generally "First In-First Out", passenger ships, navy ships and livestock carriers have priority over other types of vessels.

$\mathrm{MPR}=\mathrm{NAV}>\mathrm{G} 12=\mathrm{G} 3=\mathrm{G} 4=\mathrm{G} 5=\mathrm{T} 12=\mathrm{T} 3=\mathrm{T} 4=\mathrm{T} 5$ is found satisfactory for the purpose of this simulation study for daylight hours. At night there are extra conditions that force some large ships to wait until sunrise. This is also designed into the algorithm. 
Table 3. Ships Requiring Pilotage Service + Ship Type.

\begin{tabular}{|c|c|c|c|c|c|c|}
\hline & \multicolumn{3}{|c|}{ North Bound } & \multicolumn{3}{|c|}{ South Bound } \\
\hline & Total & Requested Pilotage & $\%$ & Total & Requested Pilotage & $\%$ \\
\hline MPR + NAV & 681 & 536 & 79 & 695 & 547 & 79 \\
\hline G12 & 32886 & 13134 & 40 & 32728 & 11731 & 36 \\
\hline G3 & 5874 & 4638 & 79 & 5966 & 4767 & 80 \\
\hline G4 & 554 & 554 & 100 & 588 & 588 & 100 \\
\hline G5 & 6 & 6 & 100 & 6 & 6 & 100 \\
\hline T12 & 5163 & 2906 & 56 & 5345 & 2652 & 50 \\
\hline T3 & 4463 & 4351 & 97 & 4417 & 4326 & 98 \\
\hline T4-T5 & 670 & 670 & 100 & 648 & 648 & 100 \\
\hline TOTAL & 50297 & 26795 & 53 & 50393 & 25265 & 50 \\
\hline
\end{tabular}

Source: KEGM 2010-2011 Data

3.3. Algorithm. There are different parts of this model. All the above data is designed into the code below as in the real system. This pseudocode has already been presented by the authors (Ucan and Nas, 2013). Such an algorithm in pseudocode can be written as follows;

3.3.1. Time Creation. Even though different simulation software might have an internal clock, due to discrete event simulation specifications it is safer to create a time logic to specify important times.

The first part is the checking of daylight. 12 hour daylight is taken as average for the purpose of this simulation.

- Create 1 entity at experiment start (Experiment time 1000)

- Assign entity that sun is up.

- Delay entity for 480 minutes (8 hours).

- Assign entity that sun is down. (Experiment time 1800)

- Delay entity for 720 minutes (12 hours).

- Assign entity that sun is up. (Experiment time 0600)

- Delay entity for 240 minutes (4 hours).

- Loop entity to line 3 .

A different time logic must be created to check the availability of the Strait for North to South or South to North traffic. This is a rough guide to see which side of the passage must be open for the strait in any given time in the experiment. This logic will be evaluated with other considerations.

- Create 1 entity at experiment start (Experiment time 1000)

- Assign entity that Strait is open from South to North

- Delay entity for 720 minutes (12 hours).

- Assign entity that Strait is open from North to South. (Experiment time 2200)

- Delay entity for 720 minutes (12 hours).

- Loop entity to line 2 .

Also a different time logic must be created for pilot transfer times, as it will be unnecessary to send pilots to a pilot station when the traffic will shift its directions before the pilots arrive. 
- Create 1 entity at experiment start (Experiment time 1000)

- Assign entity that transfer is allowed from North station to South station.

- Delay entity for 660 minutes (11 hours).

- Assign entity that transfer is not allowed. (Too late for transfer)

- Delay entity for 60 minutes (1 hours).

- Assign entity that transfer is allowed from South station to North station.

- Delay entity for 660 minutes (11 hours).

- Assign entity that transfer is not allowed. (Too late for transfer)

- Loop entity to line 2 .

3.3.2. Queues Creation. There are four queues in this model. Two for pilot station and pilots and two for arriving ships from the two sides of the Straits.

For pilots;

- Create number of pilots required at experiment start.

- Assign each entity a name to distinguish them in the model.

- Mark each pilot's time now in experiment.

- Send each pilot to first queue.

- Name the queue Pilot Station South.

- Queue ranking First In First Out.

- Create a Queue for North Pilot Station.

- Queue ranking First In First Out.

The other two queues have more sophisticated models and will be explained in Istanbul Strait Models.

\subsubsection{Istanbul Strait Models.}

- Create ships according to exponential spread.

- Assign created ships type

- Branch ships according to their type

- Assign ships a priority for the Entrance Queue according to their type

- Assign a random pilot request to ships based on their type and KEGM data

- For ship types that require daylight to pass through strait check if sun is up, if sun is up give them highest priority for strait. If sun is down delay them 60 minutes and send them to line 4

- Check if ship has requested pilot and update priority over pilotless ships.

- Put ships in a queue (Istanbul Strait South Entrance)

- Queue ranking rule is lowest priority first

- Seize entities from queue if Strait is open for transit for correct direction. If not do not accept ships to Strait.

- If Istanbul Strait is open seize the highest priority ship from queue first in first out between two same priorities.

- If ship requested pilot check availability of pilot in pilot station, if there is no pilot delay ship for 10 minutes and send back to queue.

- Use strait as a resource

- Release resource after 10 minutes for ships requesting pilot and 8 minutes for other ships.

- Check if ship requested pilot

- Take a pilot from South Pilot station 
- Mark time for specific pilot. Subtract time from the pilot's arrival time to pilot station queue.

- Record time as Rest period, record pilot name, record experiment time. (This data will be analysed to see pilot resting times)

- Delay pilot in ship according to average time from KEGM statistics.

- Drop off pilot from ship

- Mark dropped off pilot's time now in experiment

- Send pilot to next station

- Dispose of the ship that completes its transit of the Strait.

We create the same model for the other direction of the Istanbul Strait passage. Here the most important part is marking times of each pilot before entering the pilot station queue and after exiting from the pilot station queue.

3.3.4. Restrictions of the Model. Even though the purpose of the study was to find the required number of pilots in the Istanbul Strait following criteria have been omitted.

- Increased fatigue factor of harder manoeuvres or troublesome ships.

- Different fatigue factor of different vessel types.

- Any other work-related exercises that maybe performed when a pilot arrives at a pilot station.

- Duration in pilot boat from pilot station to ship and vice versa.

Also environmental factors were omitted because they would only make resting hours longer due to stoppage in Istanbul Strait traffic.

- Closures in the Istanbul Strait due to environmental conditions. (Severe weather, fog etc.)

- Pilots who might be stuck on a vessel due to the vessel's mechanical problems

- Accidents which may cause closures in Istanbul Strait

- Pilot transfer duration had been taken as deterministic even though in reality it is stochastic.

The following regulatory and motivational criteria had been omitted.

- Difference between Senior Strait Pilot and Strait Pilot.

- Monetary incentives as extra income for serviced vessel per pilot

- Health issues that may cause Strait pilots to be absent for the shift.

3.4. Choosing the Performance Criteria. Choosing the performance criteria, the resting hour requirements for maritime pilots, was not an easy decision. The Maritime Labour Convention (MLC, 2006) has a rule for seamen who keep watches on board vessels. But this rule was not compatible with the requirements of the pilotage service, and some countries do not accept pilots as seamen for the purposes of working time rules (Transport Malta, 2013). USA and Australia have some special resting hours procedures for pilots but most of such rules are territorial and do not comply with Istanbul pilotage requirements (AMSA, 2013; 2010; EMPA, 2007). KEGM has a clear rule for resting hours but then it is not an easily quantifiable one for designing into an algorithm. KEGM's rule as a government regulation can be phrased as "All pilots must sufficiently rest before serving on duty" (Official Gazette, 2006). Thus after consultation with KEGM, the authors of this paper concluded that it is acceptable that 


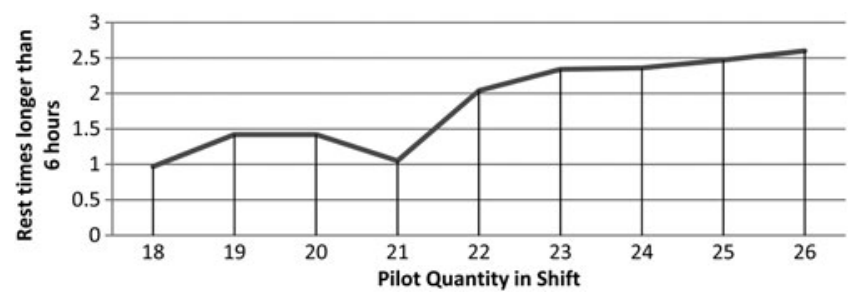

Figure 5. Average number of two 6 hours uninterrupted resting times compared to increasing number of pilots on duty.

Istanbul Strait pilots must rest at least six hours uninterrupted for a day and in their pilot duty (two days on) they should have at least two six hour periods of uninterrupted resting time, and their total daily resting time should be at least 12 hours. This rule is confirmed satisfactory with Istanbul Strait Pilots and then accepted as the performance criteria for the optimisation experiments.

3.5. Reliability and Validity. All models must be checked for reliability and validity. For reliability the model is checked to see if it is working as intended by its designer. In validity the model is compared against the system it is mimicking and if it is giving the same results as the real system as long as starting inputs are same (Chung, 2003). For reliability tests, 200 ships were created in the simulation and 200 ships were observed leaving the system. All pilots must have serviced vessels in equal numbers regardless of the pilot numbers on duty. It had been confirmed that each pilot was servicing vessels as much as any other pilot. Actually the first pilots on the queue had been generally serving one more vessel, which was confirmed as actually a problem of the system by Istanbul Strait pilots, thus it is accepted as reliable and valid. Frequency of the ship types generated should have been same as the algorithm. When the output was analysed it was noted that they were same. For validity tests, the same number of pilots as in the real system were used in the simulation experiment. Rest hours and average number of vessels served by a pilot was confirmed by direct consultation with the Instanbul Strait pilots. Statistical output data was confirmed against KEGM statistical data. All were found satisfactory.

4. RESULTS OF SIMULATION EXPERIMENTS. To find the required number of maritime pilots for the Istanbul Strait pilotage service the designed model has been rerun by input of different numbers of pilots until the performance criteria is achieved. Experiments were started with 18 pilots on duty for a two day duration of shift and numbers of pilots were increased by one for progressive runs up to 26 pilots on duty. Each experiment has been run for 20 consecutive shifts. In Figure 5 the average number of two six hour uninterrupted resting times are presented.

Even though the experiment results of 22 pilots on duty were showing an average of two six hour uninterrupted resting times for 20 consecutive shifts, the detailed analysis of the experiment has shown that there were pilots who could not rest for six hours in some shifts and only as an average was the result shown achieved. Details of that 


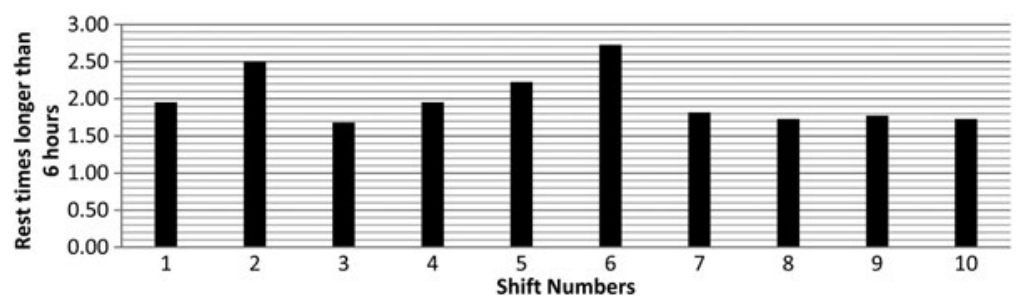

Figure 6. Average number of two longer than six hours uninterrupted resting times compared for consecutive shifts for 22 pilots on duty.

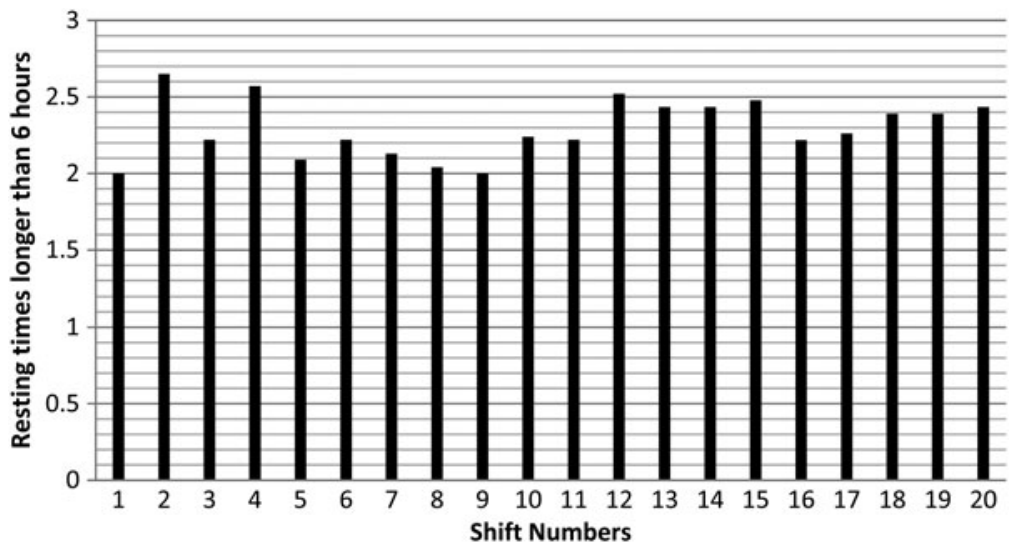

Figure 7. Average number of two longer than six hours uninterrupted resting times compared for consecutive shifts for 22 pilots on duty.

Table 4. Details of the experiment, 23 pilots on duty and 20 consecutive shifts.

\begin{tabular}{ll}
\hline Run time of the experiment (12 days warm up excluded) & $\mathbf{4 0 ~ d a y s ( 2 0 ~ s h i f t s )}$ \\
\hline Created number of ships (1/9 year) & 5642 \\
Number of pilot boarded vessels in the experiments & $2842(\% 50 \cdot 37)$ \\
Average number of vessels boarded by a pilot on duty & $6 \cdot 2 \mathrm{ship}$ \\
Average resting time for a pilot on duty & $1845 \mathrm{~min} .(30 \cdot 8$ hour) \\
Average working time for a pilot on duty & $1035 \mathrm{~min} .(17 \cdot 2$ hour) \\
Number of vessels stuck on system due to pilot shortage & None \\
Lock down of Istanbul Strait due to pilot shortage & None
\end{tabular}

experiment's first ten shifts are presented in Figure 6. Clearly it can be seen that in some shifts pilots could not have achieved the performance criteria.

The optimum number was achieved when there were 23 pilots on duty for the two days shift time. The detail of the experiment is given below in Figure 7. Twenty consecutive shifts are analysed for the required confidence interval. As can be seen in Figure 7, there were no shifts with less than two average number of resting times for each shift.

The same experiment details are also presented in Table 4 for reference and validity and reliability checks. 
5. CONCLUSION. This paper has developed a new tool for maritime decision makers. Twenty-three pilots on duty per shift for the Istanbul Strait pilotage is found to be the optimum solution with a mathematical model designed to analyse the pilotage service for this area. As this work was developed, there were 22-23 pilots employed at Istanbul Strait per shift. Thus it is clear that computer simulation experiments when designed in detail can give realistic solutions, potentially as good as experienced decision makers and can support their decisions with scientific accuracy.

It is known that maritime decision makers are consulting computer-based simulations for coastal facility risk assessments and navigation risks but authors of this paper have observed that simulation and modelling techniques are often neglected for decision making in other resource allocation problems in the maritime industry.

As further research, even though these series of simulation experiments have proven accurate compared to the real life solution for the complex problem selected, all restrictions of the mathematical model can be re-evaluated and designed into the model so even better experiments can be conducted in the future.

\section{ACKNOWLEDGEMENT}

The authors acknowledge Turkey's Directorate General of Coastal Safety's contributions to the study and thoroughly thank the distinguished institution.

\section{REFERENCES}

Akten, N. (2003). Istanbul Strait (Bosphorus): the seaway separating the continents with its dense shipping traffic. Turkish Journal of Marine Sciences, 9(3), 241-265.

AMSA. (2010). ATSB Transport Safety Report, Marine Safety Issue Investigation. Final. Retrieved from http://atsb.gov.au/media/4025579/MI2010011_FINAL.pdf (22 June 2013).

AMSA. (2013). Fatigue Risk Management Plan, The Default Plan. Retrieved from https://www.amsa.gov.au/ forms-and-publications/Publications/AMSA406.pdf (22 June 2013).

Başaraner, M., Yücel, M. A., and Özmen, Ç. (2011). İstanbul Boğazı'nda Transit Gemilerin Kullandı̆̆ı Seyir Rotalarının Coğrafi Bilgi Sistemi Yardımıyla İncelenmesi ve İyileştirilmesi. [Evaluation and Improvement of Navigational Routes of Vessels Passing Through Istanbul Strait by Geographical Data System]. Jeodezi, Jeoinformasyon ve Arazi Yönetimi Dergisi, 2011/3 Özel Sayı. 75-79.

Bruzzone, A.G., Mosca, R., Revetria, R., and Rapallo, S. (2000) Risk Analysis in Harbor Environments Using Simulation. Safety Science, 35, 75-86.

Chung, C. A. (Ed.). (2003). Simulation Modelling Handbook: A Practical Approach. CRC press.

Darbra, R. M., Crawford, J. F. E., Haley, C. W., and Morrison, R. J. (2007). Safety Culture and Hazard Risk Perception of Australian and New Zealand Maritime Pilots. Marine Policy, 31(6), 736-745.

Ece, N.J., (2005). İstanbul Boğazı’ndaki Deniz Kazalarının Seyir ve Çevre Güvenliği Açısından Analizi ve Zararsız Geçiş Koşullarında Değerlendirilmesi. [Analysis of Marine Accidents in Istanbul Strait based on Navigation and Environmental Safety And Evaluation of Innocent Passage Conditions]. PhD Thesis, Gazi Üniversitesi, Fen Bilimleri Enstitüsü, Kazaların Çevresel ve Teknik Araștırması Anabilim Dalı.

Eldemir, F., Camci, F., and Uysal, O. (2013). Analysis and Simulation of Istanbul Strait Marine Traffic Management Strategies. In Transportation Research Board 92nd Annual Meeting (No. 13-1024).

EMPA. (2007). San Francisco Bar Pilot Fatigue. Retrieved from http://www.empa-pilots.org/san-franciscobar-pilot-fatigue (22 June 2013)

Esmer, S. and Tuna, O. (2010). Konteyner Terminallerinde Lojistik Süreçlerin Optimizasyonu ve Bir Similasyon Modeli. [Optimization and Simulation Model of Logistical Processes in Container Terminals]. İzmir, Dokuz Eylül Yayınları.

Esmer, S., Yildiz, G., and Tuna, O. (2013). A New Simulation Modelling Approach to Continuous Berth Allocation. International Journal of Logistics Research and Applications, 16(5), 398-409. 
Gucma, M. (2008) Combination of Processing Methods for Various Simulation Data Sets. TransNav, the International Journal on Marine Navigation and Safety of Sea Transportation, 2(1), 11-15.

Harrald, J. R., Mazzuchi, T. A., Spahn, J., Van Dorpa, R., Merrick, J., Shrestha, S. and Grabowski, M. (1998) Using System Simulation to Model the Impact of Human Error in a Maritime System. Safety Science, 30, 235-247.

Inan, Y. (2004) The Europeanization of Turkey's Security Policy: Prospects and Pitfalls, A.L. Karaosmanoglu, S. Tashan (Eds.), The Turkish Straits, pp. 159-177. Ankara, Foreign Policy Institute.

Kelton, W. D., Sadowski, R. P. and Sadowski, D. A. (2002). Simulation with ARENA (2, 3-15). New York: McGraw-Hill.

Li, Q. and Fan, H.S.L. (2012). A Simulation Model for Detecting Vessel Conflicts Within a Seaport. TransNav, the International Journal on Marine Navigation and Safety of Sea Transportation, 6(1), 11-17.

Magdalino, P. (2000). The Maritime Neighborhoods of Constantinople: commercial and residential functions, sixth to twelfth centuries. Dumbarton Oaks Papers, 54, 209-226.

MLC. (2006). Maritime Labour Convention. Retrieved from http://www.ilo.org/global/standards/maritimelabour-convention/lang--en/index.htm (22 June 2013)

Nas, S. and Zorba, Y. (2012). Ship Manoeuvre Risk Assessment Report for the Petkim Container Terminal Project Report (Coastal Facility Construction Requisition Assessment which is published at Official Gazette No.27170 dated 15.03.2009 Communiqué Number: 2009 Official 2007/2). Project Report, İzmir. Unpublished manuscript.

Nas, S. (2010). "Kıyı Tesislerinin Planlama ve Tasarımında Gemi Manevraları Simülasyon Deneyleri [Ship Manoeuvre Simulation Experiments about Coastal Facility Planning and Design]" Proceedings from Türkiye'nin Kıyı ve Deniz Alanları VII. Ulusal Kongresi 27 Nisan - 1 Mayıs 2010, Volume - II, 935945. Trabzon : Kıyı Alanları Yönetimi Türkiye Milli Komitesi. İstanbul, Matbaa Çözümleri Sanayi ve Diş Ticaret Ltd. Şti.

Nas, S. (2011). Ditaş Kılavuzluk ve Römorkörcülük Hizmetleri Teșkilatında Emniyet Kültürünü Güçlendirme Çalışması Projesi [Safety Culture Empowerment Study Project In Ditas Pilotage and Tug Services Organization], Project Report, İzmir. Unpublished manuscript.

Official Gazzette, (2006). Official Gazette Turkey, 26360, Kılavuz Kaptanların Yeterlilikleri, Eğitimleri, Belgelendirilmeleri ve Çalışma Usulleri Hakkında Yönetmelik [Regulations about Maritime Pilots Competency, Training, Certification and Working Procedures]. Retrieved from http://www.mevzuat.gov. $\operatorname{tr}(22$ June 2013).

Ozbas, B., Or, I., Uluscu, O.S. and Altık, T. (2009). Simulation-Based Risk Analysis of Maritime Transit Traffic in Istanbul Strait. TransNav, the International Journal on Marine Navigation and Safety of Sea Transportation, 3(3), 295-300.

Squire, D. (2007). Time to Wake Up to the Consequences of Fatigue. The International Maritime Human Element Bulletin. Alert! Issue No.13, 2.

Transport Malta. (2013). Notice to Shipowners, Ship Operators, Managers, Masters, Owners' Representatives and Recognised Organisations. Guidelines for the Implementation of the Maritime Labour Convention 2006. Retrieved From http://www.transport.gov.mt/admin/uploads/media-library (22 June 2013).

Ucan, E. and Nas, S. (2013) "Utilization of Resources on Techno-Nautical Services By Developing A Dynamic Simulation Model: An Application on The Pilotage Service in Istanbul Strait". Proceedings of 14th Annual General Assembly of the IAMU, Constanta Maritime University, Constanta ROMANIA, October 26th-28th, 2013.

Ucan, E. (2013). Istanbul Bogazinda Kilavuzluk hizmeti veren kilavuz kaptan sayisinin simülasyon yontemiyle optimizasyonu [Optimization of maritime pilots' quantity by simulation Technique in Istanbul Strait] Unpublished master's thesis. Dokuz Eylul Universitesi, Izmir.

UNCLOS. (1982). Retrieved From http://www.un.org/depts/los/convention_agreements/texts/unclos/ unclos_e.pdf (22 June 2013)

Wenhui, Y. (2011) Heuristic Algorithm for Simulation and Optimization System of Port Tugboats Allocation. International Conference on Internet Computing and Information Services, 306-309.

Yazıc1, M.A. and Otay, E.N. (2009). A Navigation Safety Support Model for Istanbul Strait. The Journal of Navigation, 62, 609-630.

Zeng, Q. and Yang, Z. (2009). Integrating Simulation and Optimization to Schedule Loading Operations in Container Terminals. Computers \& Operations Research, 36(6), 1935-1944.

Zhang, T., Miao, M. and Jin, C. (2007). Study on Resource Allocate Of Container Yard Based on Simulation Optimization Method. Journal of System Simulation, 24, 5631-5638. 